\title{
Increased Osteoblastic Surface
}

National Cancer Institute

\section{Source}

National Cancer Institute. Increased Osteoblastic Surface. NCI Thesaurus. Code

C139149.

An increase in the amount of osteoblastic surface as compared to a standard or norm. 